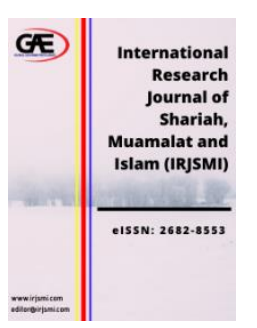

International Research Journal of Shariah, Muamalat and Islam (IRJSMI)

Journal Website: http://irjsmi.com/ eISSN: 2682-8553

\title{
THE SWOT ANALYSIS OF WAQF GOVERNANCE IN BRUNEI DARUSSALAM
}

\author{
Marina Abu Bakar ${ }^{1}$, Shofian Ahmad², Ahmad Dahlan Salleh ${ }^{3}$, Mohd Fairuz Md Salleh ${ }^{4}$
}

1 PhD student, Centre for Contemporary Fiqh and Islamic Compliance, Faculty of Islamic Studies, National University of Malaysia (UKM) \& Lecturer, Kulliyyah of Sharia and Law, Sultan Abdul Halim Mu'adzam Shah International Islamic University (UniSHAMS), Malaysia

Email: cikmarina9@gmail.com

2 Associate Prof Dr., Centre for Contemporary Fiqh and Islamic Compliance, Faculty of Islamic Studies, National University of Malaysia (UKM), Malaysia

Email: shofian@ukm.edu.my

3 Senior Lecturer, Centre for Contemporary Fiqh and Islamic Compliance, Faculty of Islamic Studies, National University of Malaysia (UKM), Malaysia

Email: dahlan@ukm.edu.my

4 Senior Lecturer, Centre for Sustainable and Inclusive Development, Faculty of Economics and Management, National University of Malaysia (UKM), Malaysia

Email: fairuz@ukm.edu.my

\section{Article Info:}

\section{Article history:}

Received date:29.01.2019

Revised date: 06.02 .2020

Accepted date: 07.02.2020

Published date: 13.03.2020

\section{To cite this document:}

Abu Bakar, M., Ahmad, S., Salleh, A. D., \& Md Salleh, M. F. (2020). The SWOT Analysis of Waqf Governance in Brunei Darussalam. International Research of Shariah, Muamalat and Islam, 2 (3), 01-22.

DOI: $10.35631 /$ IRJSMI.23001.

\begin{abstract}
:
Waqf has been practiced by the Muslim community in Brunei Darussalam since the beginning of their arrival in the country and their acceptance of Islam long years ago. In Brunei Darussalam, all matters relating to waqf are governed and administered by the Islamic Religious Council of Brunei Darussalam (MUIB) based on the provisions of the law contained in the Laws of Brunei Darussalam namely the Islamic Religious Council of Brunei Darussalam (MUIB) and the Court of the Kadi Division 77. The Act has provided that MUIB is the sole trustee of all types of waqf in Brunei. The purpose of this paper is to review the scenario of waqf governance adapted in Brunei Darussalam. The qualitative research design was adopted to provide analysis of the current practices of waqf governance. The data collected were secondary and primary data. Primary data was obtained through semi-structured interviews with waqf officers in MUIB, while secondary data were gained through published regulation and reports, journal papers, and articles. The study uses SWOT analysis in order to gain insights into the strengths, weaknesses, opportunities, and threats faced by the government of Brunei Darussalam in administering waqf. In the SWOT analysis, the strengths are the advantages of religious proposition in the country where Muslims are the majority, the successful governance practiced by MUIB and Badan Tanmiah which enable them to generate a high income and give full benefits to all the Muslims from waqf property's income and the direct financial assistance from
\end{abstract}


the government. With regard to its weakness, there are still unleashed potentials of waqf being explored, problems in human resource and management and also slow growth of waqf development compared to other neighbouring countries. The opportunities are the great potential of cash waqf and land. On the other hand, the threats comprise a lack of awareness and understanding of waqf among Muslim donators and resource limitations. Meanwhile, limited fatwa or rules gazette by the mufti in the issue of istibdal and controversy of cash waqf is considered as the other threats. These findings may help the academicians and practitioners to understand the governance issues related to waqf and further recommendations that need to be taken by the relevant parties.

Keywords:

Waqf, Governance, Brunei Darussalam, Swot Analysis

\section{Introduction}

The reality is at this time waqf property is very much stored in countries where the majority of the population is Muslim. The waqf sector that was once so powerful was developed by the Muslims as if it had lost its significance. It can be likened to a sleeping giant and needs to be rebuilt. Brunei Darussalam is one of the countries with the largest Muslim population and has the highest Islamic dignity. This can be seen with the application of the system of the Islamic Emirate which is now turned into the concept of Malay Islamic Monarchy and has been practiced since the 14th century AD. Brunei Darussalam's strength also lies in the sect held by the Brunei Muslim population that has not changed since the advent of Islam, the Sunnah Wal Jamaah. The practice of waqf in Brunei has existed since the beginning of the Brunei Darussalam Sultanate. Those days, waqf is performed traditionally whereby a waqf giver give waqf property to ustaz or religious teacher, or a community leader who later acts as a nazhir (trustee) (Gani, H. A. R., 2015). The development of the waqf management in Brunei Darussalam began in 1955 with the introduction of Brunei Darussalam National Law and the 77th Judicial Circuit Courts.

Prior to the introduction of the Brunei Darussalam National Law and the Courts of Civil Procedure 77, the government or certain parties had no right to manage and administer the waqf property in Brunei except those appointed directly by the waqf giver as nazhirs despite such an unofficial appointment. This is one of the main reasons why there is no official history of waqf management and previous waqf assets (Tamit, H. H. S., 2010). Waqf was first administered by the Government of Brunei under the management of the Brunei Islamic Religious Council (MUIB) beginning in 1955, following the introduction of waqf in the Brunei Darussalam National Law and the Supreme Courts 77.

Brunei Islamic Religious Council (MUIB) is a body in Brunei that has the authority to make regulations that will be used to determine the direction of Islamic religion in Brunei Darussalam (Brunei Darussalam Islamic Religious Council, 2019). Prior to the inauguration of the Brunei Islamic Religious Council (MUIB) in 1955 by Sultan Omar Ali Saifuddin, a body known as the Sharia Advisory Council was established in 1948 and is directly managed by the Sultan and its members (Yusof, K \& Mohiddin, F., 2011). The Islamic Religious Councils Act and the Courts of Civil Procedure 77 have stated that MUIB is responsible for all religious matters of Brunei Darussalam including zakat, waqf, baitulmal, halal certificate of pilgrimage and mosque (Brunei Darussalam Islamic Religious Council, 2018). Pursuant to Chapter 100 of the Islamic Religious Council Act and the 75th Judicial Magistrates' Courts, MUIB is the sole trustee of the securities in Brunei. It can also be concluded here that the MUIB task consists of two main Copyright (C) GLOBAL ACADEMIC EXCELLENCE (M) SDN BHD - All rights reserved 
functions. First; as the sole trustee of all baitulmal property, all waqfs, including general waqf or specific waqf, all general vows and all trusts of any kind make any charitable trusts to support and promote Islam in accordance with Islamic law. Second; became a nazhir and trustee of all mosques in Brunei Darussalam and as owner of a non-owned property and was responsible for building and demolishing existing mosques in Brunei Darussalam. The provisions of Chapter 100 are as follows:

"Notwithstanding any conflicting terms contained in any instrument or declaration governing and affecting such instrument or declaration, the Council shall be the sole trustee of all waqfs, whether general or specific waqf, for all general vows and all trusts and of any kind making any charitable trusts in support of and promoting Islamic religion in accordance with Sharia law, all property subject to it and located in Brunei Darussalam and if any resident or other person making trusts, waqf or vows It is located in Brunei Darussalam, as far as all its properties are concerned."

Looking at the background, Brunei Darussalam clearly proves that Brunei is a country upholding the Malay Islamic Monarchy philosophy and is concerned with the welfare and benefit of Muslims. Waqf can be classified as an extremely important asset of Muslims in meeting the needs and interests of Muslims both socially and economically. Therefore, good governance is very important in managing and developing waqf assets in a country. This article aims to analyse the waqf governance practiced in Brunei.

\section{Literature Review}

\section{Brunei Darussalam Islamic Religious Council (MUIB)}

\section{History of the Establishment of the Brunei Darussalam Islamic Religious Council (MUIB)}

In 1956, MUIB was established, after the Religious and Criminal Court Act 1955 was enacted in the same year. The establishment of MUIB is during the reign of His Highness the late Maulana Al-Sultan Sir Young Omar Ali Saifuddin Sa'adul Khairie Waddien, the 28th Sultan and King of the Brunei Darussalam. Originally, MUIN's name was Islamic Religious Council and State Customs. Customs is defined as Malay Customs practiced for generations and become a tradition since time immemorial in Brunei. Although, Malay customs at the time of initially receiving the influence of Hinduism, but after receiving the Brunei Islamic, Hindu influences that are contrary to Islam has been eliminated (Gani, H. A. R., 2015). Although in 1956, the Islamic Religious Council and the State Customs Council existed separately, but they were later merged into one institution namely the Religious Council and the State Customs. Following the promulgation of the Brunei Constitution 1959, MUIB has stood as a stand-alone institution and has not merged with the State Customs. The role of MUIB at this time is more important to the legislature as MUIB is responsible for planning, considering, issuing directives, regulations and making decisions for the Department of Religious Affairs to implement. Meanwhile, the Department of Religious Affairs plays the role of executive. MUIB is the highest Islamic institution that is placed directly under the authority of the Sultan. The implication is that any decision made by MUIB must be presented to the Sultan by the President of the Council and obtained by His Majesty before any implementation is forwarded to the Department of Religious Affairs. 
Authority, Duties and Responsibilities of the Brunei Islamic Religious Council (MUIB)

The authorities and responsibilities of MUIB are set out in the Islamic Religious Councils and Courts of Justice Act 77. Table 1 is a summary of the duties and responsibilities of MUIB as enshrined in the Islamic Religious Council Act and the Supreme Court of Justice 77:

Table 1: Summary of Duties and Responsibilities of MUIB in Accordance with the Islamic Religious Council and Supreme Court of Justice 77

\begin{tabular}{lll}
\hline No. Authorities and duties of Brunei & $\begin{array}{l}\text { Provisions in the Acts of the Islamic } \\
\text { Islamic Religious Council (MUIB) } \\
\text { Religious Council and the Supreme } \\
\text { Court } 77\end{array}$
\end{tabular}

1. Act as executor of a will or as administrator of a deceased person or as trustee of any trust.

2. The sole trustee of all baitulmal property, all types of waqf either Chapter 9 general waqf or specific waqf, all general vows and all trusts of any kind making any charitable trust to support and promote Islam in accordance with Islamic law.

3. Collection of all zakat and tithes paid in Chapter 114 Brunei Darussalam under Islamic law. Chapter 100 To serve as a nazhir and trustee of all

4. mosques in Brunei Darussalam together with any immovable property, of which it is located or related, and has authority to authorize the construction, repair, addition, closure and demolition of mosques in Brunei Darussalam.

Keep a list of people who revert to Islam in Brunei Darussalam and any

5. details relating to any religious Chapter 164 and 167 conversion as specify.

Giving permission for any teaching of Islam in Brunei Darussalam.

6. To authorize any donations raised to Chapter 185 support and uphold the teachings of

Chapter 101

7. Islam and the interests of Muslims Chapter 122 themselves. Appointment of eligible persons to be amil (zakat collectors) and kadi in

8. Brunei Darussalam.

Appointing the Chief Sharia Court, the Standing Committee on Sharia Appeal

9. Court Judges, Sharia High Court Judges, Sharia Subordinate Court Judges and other Sharia Court officers. Identify centres of slaughter inside and outside the country. 
10. Issuing Halal Certificate, Halal

11. Slaughter Certificate and Halal Mark for Raw Meat.

Issuing halal certificates and halal

12. permits for places of business.
Chapter 115

Chapter 116

Chapter 117

Source: Brunei Islamic Religious Council (MUIB)

Subsequently, the powers and responsibilities of MUIB are divided into several Departments that are placed under MUIB. The Brunei Islamic Religious Council Department acted as the secretariat for MUIB and its administration was placed under the Ministry of Religious Affairs. JMUIB is headed by the Secretary of the Islamic Religious Council appointed under Chapter 14 of the Islamic Religious Council and the Supreme Court of Justice 77. Among the goals of JMUIB is to help MUIB formulate policies to be implemented and implemented in Brunei, ensuring that every policy and decision of MUIB is upheld and implemented. The Islamic Religious Councils and the Supreme Court Courts 77 and the Acts or Regulations relating to MUIB effectively and efficiently administer and administer zakat, baitulmal and waqf property as well as review and examine religious and current issues for policy setting that MUIB will create. There are 6 Divisions and one Body is placed under the supervision of JMUIB; Meeting, Administration Division, Legal Division, Waqf and Baitulmal Division, Finance and Accounting Division, Zakat Collection and Distribution Division and Islamic Religious Council Property Agency. Diagram 1 below shows the position structure of MUIB, JMUIB, Parts and Body under MUIB. The authority of MUIB on waqf property is in accordance with Chapters 98 and 100 of the Islamic Religious Councils Act and the Supreme Court of Justice 77.

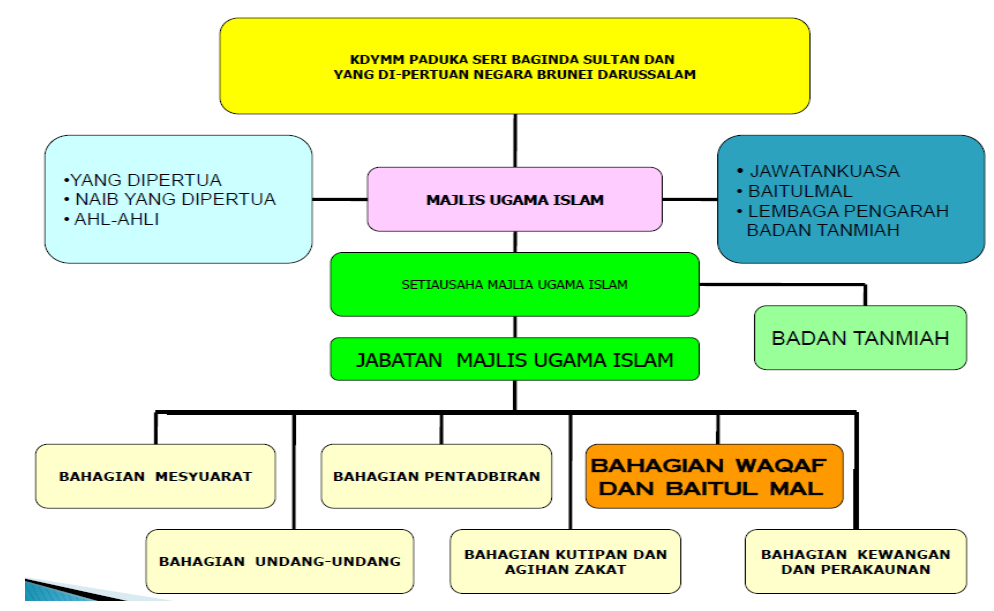

Figure 1: Structure and Position of MUIB, JMUIB, Sections and Bodies under MUIB Source: Brunei Islamic Religious Council (MUIB)

In managing and managing the day-to-day administration of the waqf property in Brunei, the Departments under the Islamic Religious Council are responsible for the assigned tasks. The waqf property registered in MUIB is managed by the Waqf and Baitulmal Divisions, one of which is under the MUIB. It will then be handed over to several sections in cooperation with the Waqf and Baitulmal Divisions according to waqf type and the intention of the waqf giver. MUIB has divided the waqf property according to certain mechanisms namely land waqf, building waqf (mosque), cash waqf and vehicle waqf and movable property. The land waqf is Copyright $\odot$ GLOBAL ACADEMIC EXCELLENCE (M) SDN BHD - All rights reserved 
managed by Real Estate Agency, building waqf (mosque) is managed by Mosque Affairs Department, cash waqf is managed by Finance and Accounting Division, while waqf of vehicles and other movable property is managed by Waqf and Baitulmal Divisions. Each of the Divisions and Bodies placed under this JMUIB has the roles and duties set out in Table 2 below:

Table 2: The Roles, Duties and Responsibilities of the Division under the Department of Islamic Religious Affairs of Brunei Darussalam (MUIB)

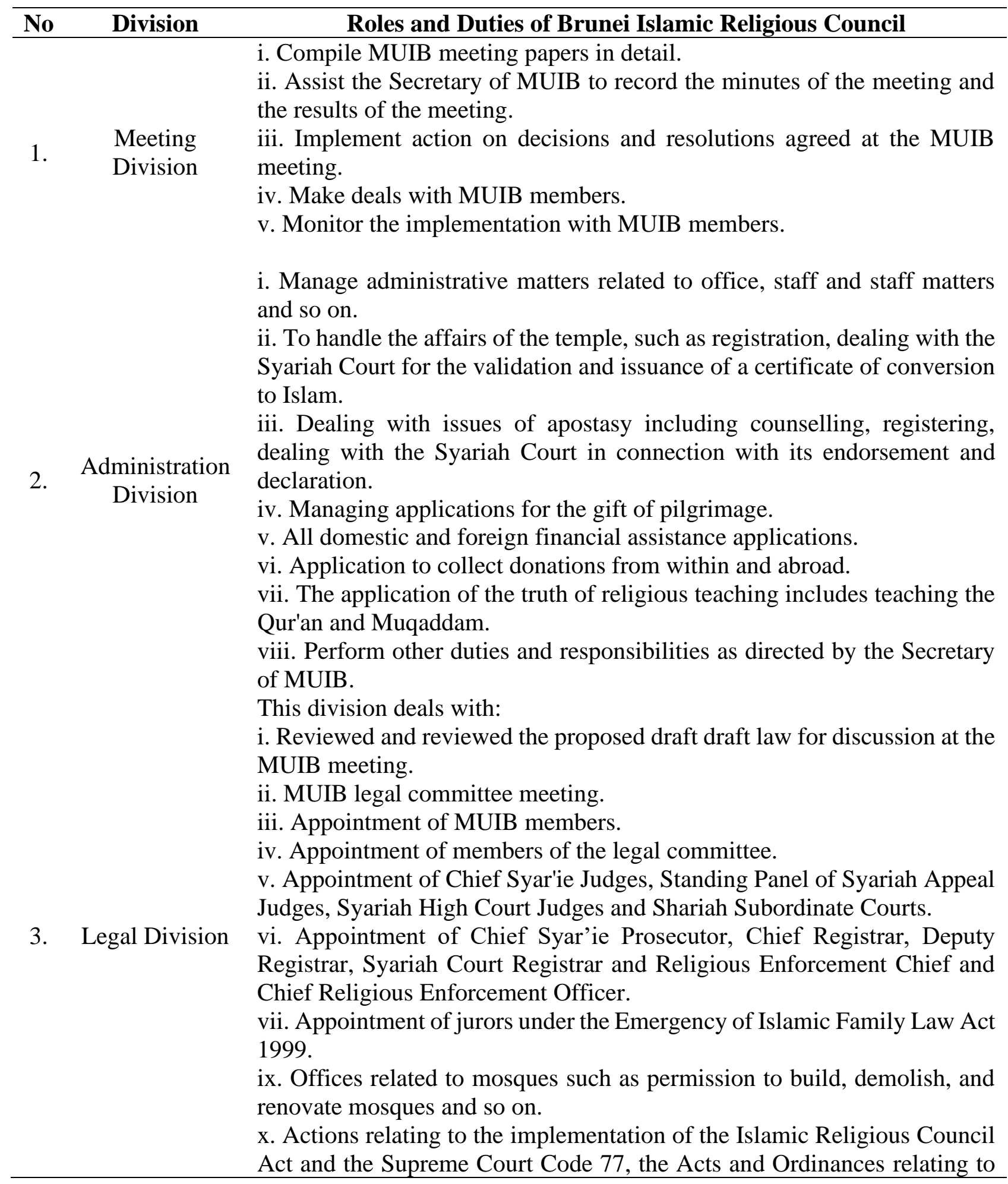


MUIB, the Implementation of the Emergency Halal Meat Emergency Order 183 and the Halal Meat Rules 1999.

The main task of this division is to manage and manage the baitulmal and waqf property in co-operation with the Finance Division of JMUIB, the affairs of the Badan Tamiah and the assistance of the baitulmal property. Other tasks include:

i. To provide a draft minute of action to the President or Vice President of MUIB, relating to the affairs of the waqf and baitulmal as well as the relationship with the Agency.

ii. Prepare meeting papers relating to wakaf and baitulmal property, as well as discussions with the Agency for preparation of MUIB conference meetings.

Waqf and
Baitul Division

iii. Act as a consultant in relation to the application of the deed and in connection with baitulmal land such as obtaining an administrative authority, land registration, application for land purchase, subdivision, customary land conversion, acquisition of baitulmal land by the government and so on.

iv. Create consultations and actions for the establishment of waqf funds. $\mathrm{v}$. Take a tour of the land or premises to be leased and a visit to the baitulmal land to be purchased, conditions changed, subdivision and so on.

vi.Update the data of wakaf property, inheritance and baitulmal land and then enter the data into computer system.

vii. Affairs relating to such departments as the Syariah Court, the Attorney General's Chambers, the Land Office and others.

viii. Perform other defined actions and tasks.

This division deals with:

i. The charity fund.

ii. General administration money.

iii. Prepare a zakat fund statement.

iv. Prepare general administration fund statement.

v. To provide annual budget estimates for MUIB department.

Financial and vi. Coordination with the relevant banks and Treasury Department of the

5. Account Ministry of Finance.

Division vii. Management of checks, vouchers, and receipts for general administration and zakat funds.

viii. General cash management of general administration funds.

ix. Managing annual expense payments using the MUIB Department's budgetary allocation.

$\mathrm{x}$. Perform other duties and responsibilities as directed by the Secretary of MUIB.

This division deals with:

i. To collect the zakat on property and baitulmal charity.

ii. Receipt and storage of zakat money.

Zakat iii. Military designation.

6. Collection and

iv. Charges and charity donations.

Distribution v. Application for asnaf eligible to receive zakat.

Division

vi. Consumption and investigation of the poor and eligible zakat teachers from time to time.

vii. Continuation and investigation of immediate emergency cases such as fire, natural disaster, illness or in the form of emergency assistance. 
viii. Provision of complete data on poor and poor donors.

ix. Perform other duties and responsibilities as directed by the Secretary of MUIB.

Source: Brunei Islamic Religious Council (MUIB)

\section{Badan Tanmiah Brunei Darussalam}

\section{The Establishment of Badan Tanmiah}

Badan Tanmiah is an agency under the Islamic Religious Council which was established on July 5, 1994 at the behest of His Majesty the Sultan and the Yang di-Pertuan Brunei Darussalam as an investment body (Islamic Religion, 2019). This body is responsible for managing part of the Islamic Religious Council's property for the purpose of expanding and developing the property for the benefit of Muslims in Brunei Darussalam (Islamic Religious Council Property Agency, 2015). On August 24, 1981, a Committee on the Study of Property Development and Investment of the Islamic Religious Council was established. The purpose of its establishment is to consider and study the possibility of expanding and investing the assets of the Islamic Religious Council, as well as providing support and recommendations to the Islamic Religious Council for consideration. Then on July 15, 1988, His Highness the Sultan and the King of Brunei Darussalam were present at the 42nd Anniversary of His Royal Highness at the Palace of Nurul Iman. He said:

"In the field of religion, the Government will continue to promote from time to time efforts for the purpose of upholding the purity of Islam and balancing development and progress in the material field. In addition to striving to further the teaching of Islamic religion, the Government is also considering the idea of utilizing the accumulated wealth in Baitulmal for the benefit of taxation as required by Islamic religion."

Subsequently, on September 25, 1990, he went to the Islamic Religious Council Conference at the Ministry of Religious Affairs (KHEU), Bandar Seri Begawan. His Majesty emphasized on the importance of developing baitulmal property for the benefit of Muslims especially as a foreseeable future in this conference. The Structure, a Special Committee for the Establishment of the Islamic Religious Council Investment Unit, was formed on August 26, 1993. It is responsible for providing the requirements for the establishment of such units such as the structure of salaries and personnel, the limits of freedom of movement to enable it to operate as a business operation, other requirements for the unit.

The proposal to set up this investment unit was approved by His Majesty the Sultan and the President of the Brunei Darussalam. He named it the Islamic Religious Council Property Council on July 5, 1994. The Islamic Religious Council Property Authority is a body that manages and manages the affairs of the Islamic Religious Council from the General Administration Fund by implementing appropriate investment plans. As a result of its establishment, the Islamic Religious Council Property Development and Investment Committee was formally dissolved and replaced by the Islamic Religious Council Property Council Advisory Committee. The Islamic Religious Council Property Authority officially came into operation on September 4, 1995 and operates at Unit 22, Block B, Baitulmal Commercial Building Jalan Batu, Brunei Darussalam. Finally, on August 23, 2001, the first Board of Directors was formed at the behest of His Majesty the Sultan and the President of the Brunei Darussalam. The members of the Board appointed are experienced and experienced in their respective fields. 


\section{Vision and Mission of Badan Tanmiah}

The vision and mission of the organization is fundamental to integrating all strategic initiatives undertaken by organizations with core services delivered together. An effective collaborative management system helps organizations define and direct their core processes to all levels and divisions within them. Badan Tanmiah is an organization operating on its vision of expanding and developing the Islamic Religious Council's property through a well-organized and effective development plan and Islamic investment. Meanwhile, the mission of Badan Tanmiah is to develop, develop and enhance property through a Sharia-compliant and risk-free investment plan (Badan Tanmiah Harta Majlis Ugama Islam, 2019).

\section{Functions and Objectives of Badan Tanmiah}

There are two main functions of Badan Tanmiah in the planning and implementation of Islamic Religious Council Property Investment Plans as well as managing the Islamic Religious Council's real estate affairs in terms of marketing, maintenance and administration. As an agency that plays a key role in the development and development of Islamic Religious Council property, it operates on two main goals; develops and develops existing assets through investment plans with reasonable returns and engages in the welfare and livelihoods of Muslims. Involvement in the affairs of the welfare and life of Muslims is carried out through aid programs such as prayer and prayer centres, donations to charities and non-governmental organizations by engaging in activities organized by them, indirectly through investment plans, the provision of employment and income opportunities for Muslim youth and the provision of experience and skills to Muslims to thrive in the economy.

\section{Board of Directors and Functions of Sections of Badan Tanmiah}

Figure 2 below shows the positions and jurisdictions between MUIB, the Board of Directors and the Real Estate Agency. MUIB is assisted by the Board of Directors and the Real Estate Agency in the management of waqf land. From 2016 to 2019, Badan Tanmiah has a number of Board Members consisting of a Chairman, a Deputy Chairman, a Secretary and 8 ordinary members.

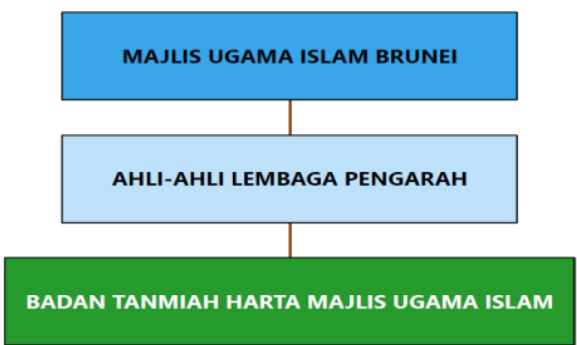

Figure 2: Position and Jurisdiction between MUIB, Board Members and Badan Tanmiah

Source: Badan Tanmiah

Figure 3 shows the management structure of the waqf property by the Badan Tanmiah at the operational level. Badan Tanmiah is divided into 4 sections namely the Corporate Governance, Finance, Investment and Property Management sections and the Project Management and Estate Conservation Section. Each section is managed by a Director and a Deputy Director. Both were assisted by a Confidential Secretary. Each Section is managed by a Senior Manager, a Manager and several other Assistant Managers. Some of these Assistant Managers are further assisted by support staff such as Finance Clerk, General Clerk, Technical Assistant and Office Assistant. 


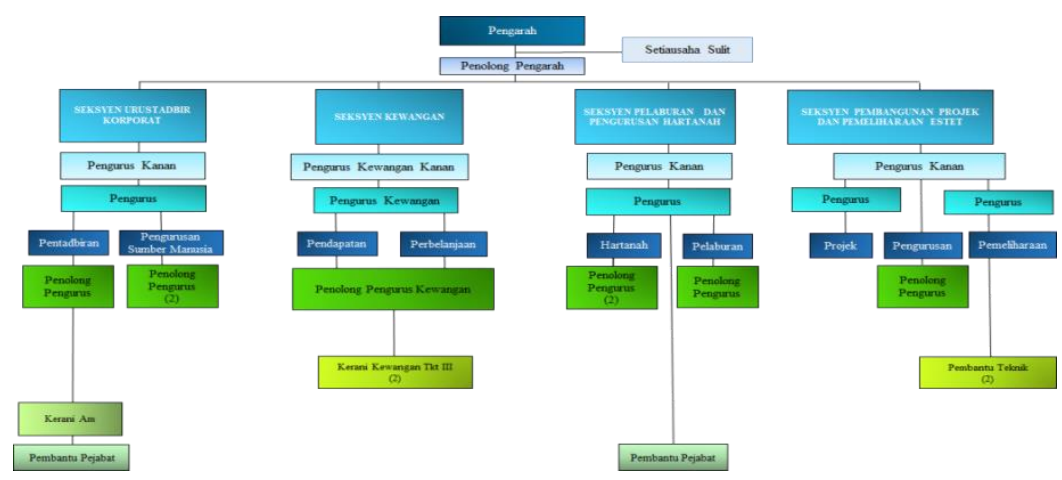

Source: Badan Tanmiah

Figure 3. Organization Structure of Badan Tanmiah.

The Corporate Governance Section acts as a liaison agent among other sections through the provision of matters relating to the office or personal office of the Officers and Staff of Badan Tanmiah (Interview, 2019b). The Finance Section plays a role in monitoring the control of office operating costs and investment projects. These include matters relating to the management of expenditure, income, accounting, budget allocation and management of fixed assets. The Investment and Property Management Section is a key part of achieving the vision and mission of developing and developing existing property through building and land lease plans and investment opportunities with the aim of making a reasonable return to the Badan Tanmiah. In the meantime, the Project Management and Estate Conservation Section is responsible for planning and managing the construction projects of the new Land Agency as well as carrying out the tasks of managing the board (Badan Tanmiah). The specific tasks for each section are summarized as shown in Table 3. From 1992 to 2019, Badan Tanmiah has successfully developed several canoe projects in Brunei. The list of waqf projects developed is briefly described in Table 4.

Table 3: Summary of Special Task Sections in Badan Tanmiah

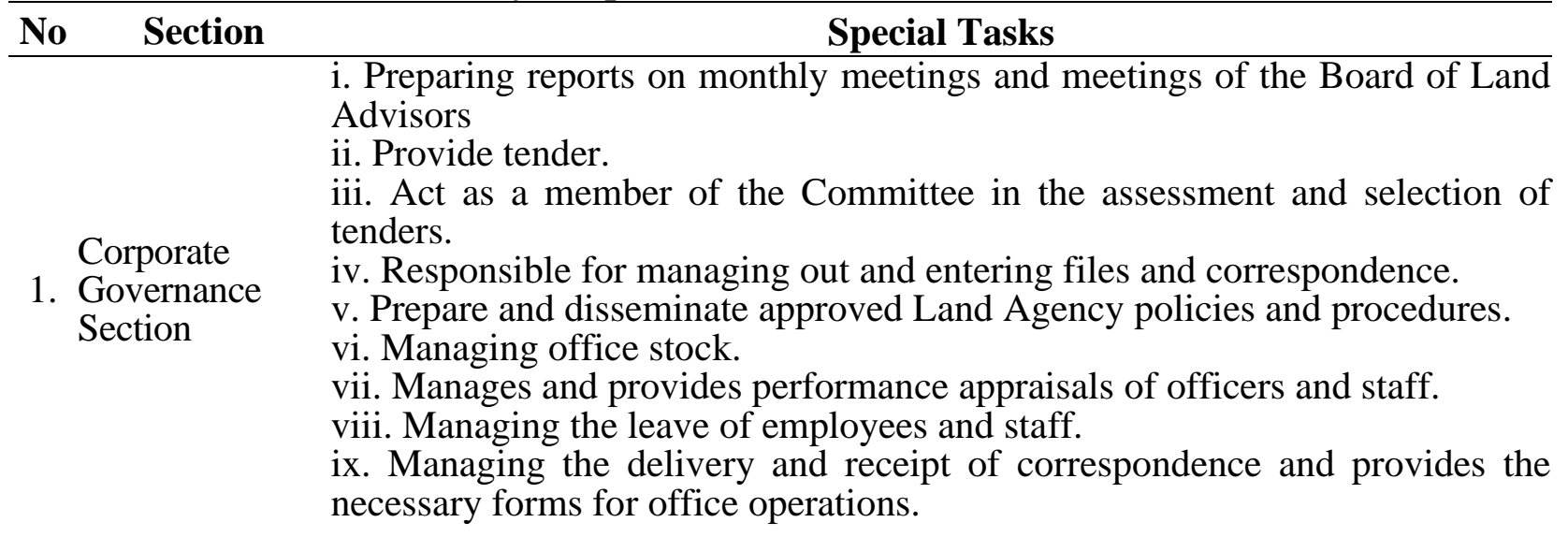


2. Financial Section and

3. Property Management Section
Investment

i. Monitoring revenue collection and ensuring expenditure of financial use in accordance with Land Agency policies and procedures.

ii. Acting as a member of the Appraisal and Selection Committee

iii. Preparing monthly cash flow statement reports to be submitted to MUIB and members of the Board of Directors.

iv. Preparing financial reports for meetings of the Board.

$\mathrm{v}$. To monitor and record the list of fixed assets and matters relating to disposal.

vi. Responsible for preparing budget allocations and financial statements of the Agency annually.

vi. Collaborate with auditors on audit matters.

i. Carrying out promotions and surveys of the real estate market in formulating effective market strategies, particularly in an effort to increase the number of tenants in the Real Estate buildings as well as the rental of Baitulmal lands.

ii. Developing a survey to identify potential Baitulmal lands for development in the interest of the Land Agency.

iii. Conducting surveys and investment planning in business.

iv. Responsible for monitoring the growth of subsidiaries.

v. Collaborate with the finance section in monitoring rental and debt service matters.

vi. Dealing with a lawyer appointed by the Badan Tanmiah in the preparation of rent-to-lease agreements, debt claims and so on.

i. Make sure that maintenance plans and repairs are completed in accordance with the budget allocation. This plan is being implemented based on the 'forecast plan'

Project of this section, in accordance with the plans provided.

Management ii. To take immediate action against complaints of damage.

4. and Estate

Conservation

Section iii. Monitor building maintenance expenses by repairing minor damage such as fan and lamp replacement.

iv. Improving the performance of management matters in this section.

v. Increasing the expertise of the members of this section through courses related to it.

Source: Badan Tanmiah

Table 4: List of Waqf Projects by Badan Tanmiah (1992-2019)

No Waqf Projects Detail

- Completed on February 2, 1992.

- The total cost is B \$311,926.80.

1. Rumah 2 Tingkat, Lot 13712 Kampong

- Rented by KHEU on January 1, 1993.

1. Sg Hanching

- Monthly rent of B \$ 3,200 (from January 1, 1993 to May 14, 1998).

- Monthly rent of B \$ 2,500.00 (May 15, 1998 to date).

- - Consists of 2 blocks. Each block has 24 units.

- Built on April 23, 1994.

2. Business Complex, Kg Kota Batu

-The total cost is B $\$ 5,858,904.22$ which is; Block A amounted to B $\$ 3,049,674.10$ and Block B amounted to B \$2,809,230.12.

- Block A was leased by KHEU on March 13, 1996.

- A monthly rent of B \$33,600.00.

3. Residential Building, Kg Selayu Sengkurong - Block B was leased on Sept 1, 1994. of Class C) 


\section{Residential Building, Kg Keriam Tutong}

5. Residential Building, Kg Tungku

6. Residential Building, Kota Batu

7. Petrol Station, Kg Kuala Lurah

8. Business Complex, Kg. Kuala Lurah
- Completed on September 14, 1994 at a total cost of B $\$ 5,673,329.46$.

- Consists of 20 units (4 Class B units, 8 Class C units and 8 Class $\mathrm{G}$ units)

- Completed on October 31, 1994.

- The total cost is \$5,626,957.26

- Rent by KHEU starting August 17, 1995.

- Monthly rental rates range from B \$31,400.00 to B \$ 30,550.00.

- Consists of 8 units.

- Built on December 8, 1999

- The total cost is B \$952,725.37

- Rented by KHEU from April 20, 2000 to the present.

- Monthly rental rates range from B \$ 8,750 to B \$ 8,550 .

- Consists of 2 Blocks (Each block has 24 units)

- Completed on May 15, 2000

- The total cost is B \$3,324,703.99

- Rented by the Ministry of Defense from December 19, 2000 to the present.

- The monthly rent is B \$31,200.

- Completed on February 12, 2001.

- The total cost is B $\$ 1,203,943.81$.

- Officially opened on August 23, 2000.

- Consists of 24 units.

- Completed on April 7, 2001.

- The total cost is B \$2,943.1 62.67.

- Rented to Brunei community since April 1, 2002 (Lower level B \$ 1000, First floor B \$ 600).

- From March 1, 2003 to date, rent rates have been B $\$ 600$ for the first floor and B \$ 400.00 for the 1st Floor.

Source: Badan Tanmiah; Abu Bakar, M. (2019).

\section{Methodology}

This study uses qualitative methods and aims to analyse the governance of waqf in Brunei Darussalam using SWOT approach. The findings of this study were collected through library studies, documents and semi-structured interviews with officials of the Brunei Islamic Religious Council (MUIB) and the Brunei Darussalam Property Bureau (BT). The process of data analysis involves descriptive analysis methods. Data analysis employs a SWOT analysis approach to find out the strengths, weaknesses, opportunities and threats of waqf governance practices involving MUIB and Badan Tanmiah. Both institutions were selected for their direct involvement in the administration and management of waqf assets in Brunei Darussalam. SWOT is one of the techniques of organizational analysis to find out how the current state of the organization relates to the situation and what the future holds in terms of strengths, weaknesses, opportunities and threats. According to Rangkuti (2000), SWOT analysis is a process of identifying external and internal factors that influence the action or implementation of a strategy that an organization will pursue in achieving the goals, visions and mission of the organization. In this study, strength refers to the advantages, privileges or abilities that the organization itself does not have. This will give the organization a competitive edge. Weaknesses are a business or company situation facing a competitor with limitations and shortcomings and the ability to master the market, resources and expertise. The weaknesses 
that are inherent in an organization are the limitations or disadvantages of resources including resources, expertise and raw materials, skills and capabilities that are the major barriers to successful organizational performance. Opportunities are defined as opportunities that exist for the organization to grow. Organizational development can be achieved through new or innovative discoveries identified in the market. Marketplace changes offer a variety of opportunities to benefit from the organization. This makes an organization more competitive than its main competitors and can move into new markets. Threat is any possibility that involves external factors that could disrupt the organization's movement and progress. A change in the external environment can also pose a threat to the organization, company or business. Threats are conditions that threaten the external environment. Threat analysis is more about assessing what obstacles to overcome. In SWOT analysis, threats refer to risk management. Indirectly we can determine the best way to resolve a problem or obstacle. With this analysis, a plan can work well, and an organization needs to identify and list the threats and factors that hinder success.

\section{Results}

\section{SWOT Analysis}

\section{Strengths}

Brunei Darussalam has a predominantly Muslim population and upholds the philosophy of Islamic conceptual government. The Muslim community in the country is receiving direct financial assistance from the Sultan of Brunei especially in matters related to Islamic religion as examples in mosque development, religious schools, financial aid and the provision for eradicating poverty. Brunei's strong economic position and as a developing country have led to a good standard of living of the Muslim community, with the exception of no taxes imposed on the people of Brunei and the majority of their citizens enjoying a comfortable monthly income. This also led to MUIB's governing body under the Sultan of Brunei gaining the attention and support of the government especially in matters of Islam and waqf.

Funds are a very important factor in managing the development and investment of waqf real estate. The source of funds to fund waqf projects in Badan Tanmiah came from MUIB, which is through the baitulmal property that is placed under the General Administration Fund. However, prior to the granting of funds by MUIB, the Agency is required to submit a budget application to MUIB in the form of a proposal and will be brought to the meeting for joint discussion. The meeting was also attended by His Royal Highness the Sultan and His Royal Highness Brunei Darussalam for his approval. In terms of practice, MUIB will approve the amount of the budget requested Badan Tanmiah by the rate requested, taking into account the annual budget amount that MUIB has limited. After approval has been received by the MUIB they will inform the Board for further action. Badan Tanmiah will make any decision and will then extend it to MUIB. Once the decision is received by the MUIB, Badan Tanmiah will begin the process of developing the waqf property as approved and once the building is completed, Badan Tanmiah will open a rent ad for the premises.

The forms of real estate investment planned by Badan Tanmiah are commercial forms such as business buildings, offices and housing. The rental rate of the premises set by Badan Tanmiah is in accordance with the current rental rate. However, the income of the Board is highly dependent on the current economic situation. During the recession, around 1997 to 1998, Badan Tanmiah also suffered financial difficulties when it had to lower building rental rates to B \$ 400 to B \$ 500 a month. From the accounting aspect, prior to 2003, all income derived from 
Badan Tanmiah will be consolidated and included in the General Administration Fund of the Brunei Islamic Religious Council. However, in 2003, all the proceeds received by Badan Tanmiah including the rental income of the waqf property were included in the personal account of Badan Tanmiah. Badan Tanmiah will use the proceeds to pay the salaries of employees working at Badan Tanmiah, building maintenance expenses and making new investments. With the existence of a private account of Badan Tanmiah, all matters of repairs and maintenance of the building can be carried out more efficiently as Badan Tanmiah can continue to deal with the damage that may arise in the event of any complaint without the need for permission as per the procedures of the government departments in Brunei Darussalam.

In addition, Badan Tanmiah also pays all land taxes for the buildings under its management. In this regard, Badan Tanmiah does not face any problems as the value of the tax is not very high, but the annual return from the buildings under its management can also cover the expenses of the tax due. For example, the waqf land for Lot 11106 Kampong Kota Batu is worth B \$ 875 a year and the waqf lot 11613 Kampong Kota Batu is worth B \$1,250. However, there are also cases of waqf land that can't be determined land value tax as it is state-owned land gazette as waqf land Lot 3850 Kampong Melayu Asli. In terms of building maintenance and management, Badan Tanmiah is fully responsible for ensuring that these maintenance plans and repairs are in accordance with the budget allocations. In addition, plans for repairs are carried out under the forecast plan under the Project Management and Estate Maintenance Section. Badan Tanmiah is also able to deal with complaints of minor damage to buildings without relying on specific contractors or companies to avoid higher expenses. In managing productive waqfs, the Badan Tanmiah has also made direct investments in waqf properties, such as land and buildings by applying for rent or Al-Ijarah contracts. In fact, the productive model of waqf management practiced by Badan Tanmiah is through the distribution of waqf products to various profitable sectors such as housing, gas stations, business facilities, and other halal businesses. The main strategy of development implemented by the Board is to use cautious approach and wise investment selection. Thus, Badan Tanmiah focuses on key aspects such as land and building construction and its management and this includes active investment. Meanwhile, for waqf real estate investment, Badan Tanmiah generally offers leasing schemes aimed at increasing institutional income, avoiding capital from agencies, helping to develop local businesses, boosting land market value, and stimulating economic activity in those lands unmanaged.

For example, Badan Tanmiah commenced construction on vacant land where it was fully funded by Badan Tanmiah itself. The building will then be leased through two methods of renting: a primary tenant or a single tenant, involving only one tenant. This is to ensure a long lease term based on the good tenant reputation and stable income of the Badan Tanmiah. The second is through a large number of tenants and is a common method of renting to individuals or companies. In addition, Badan Tanmiah has adopted a funding partnership to invest in waqf properties. One of the main objectives of financing this form is good capital rationing as well as reducing the risk of financing more agencies. However, the focus of development on vacant land is only in strategic areas. Parties such as local banks will be asked to collaborate in support of Baitulmal by investing capital funds into planned development. Generally, the parties involved must have a good reputation and a strong financial background.

Badan Tanmiah has also put in place another strategy to increase investment in waqf real estate in Brunei by involving agencies in producing and participating in the purchase of low-risk Islamic financial products, which can provide stable short-term and long-term income such as Investment Trust Property or otherwise known as Real Estate Investment Trust (REIT) and others. However, the value of the investment obtained is not very impressive. In the context of 
Brunei, Badan Tanmiah is not allowed to use cash waffles for community programs such as micro finance or in the form of business assistance. Although micro-financial assistance provided in reality is guided by financial experts who will provide training to those microcreditors and teach them how to do business well, it is still not allowed because there are no specific laws regarding the matter at Brunei Darussalam.

Proceeds from the various waqf real estate investments will be distributed to the needs of poor children and orphans in Brunei Darussalam through various programs and activities that meet the needs of education, health and social services. Crown Al-Muhtadee Billah's Young People's Fund has been established for the benefit of orphans, and the Agency has also sponsored a special student orphanage plan through this fund. Badan Tanmiah contributes B \$ 3,600 to this takaful plan each year, contributes financially to the Sultan Haji Hassanah Bolkiah Foundation, runs prayer projects and prayer houses around the country, provides assistance to muallafs to renovate homes and finance the Badan Tamniah's staffing courses at within and outside Brunei Darussalam.

However, the most widely used waqf property investment is to meet the needs of the education sector, followed by the health sector, the religious sector and finally the social sector (Hubur, AA., 2019). Education is one of the basic requirements under the government of Brunei Darussalam because the people of Brunei are free to access free education at no cost, from primary to higher education. All the facilities at the government school received assistance from His Highness the Sultan and the Sultan. In fact, every student receives scholarship money every month. The Brunei Islamic Religious Council also provided assistance from the investment of waqf real estate to those in need, although almost all of Brunei's were not poor. In 1998, the Agency made a first donation of B \$ 10,000,000 from the Crown Prince AlMuhtadee Billah Fund, including a waqf fund for the welfare of orphans. There are also proceeds from the investment of waffles that are channelled to health facilities such as hospital development and hospital facilities. In addition to the funding provided by the Brunei government, there is also a fundraising from the waqf investment owned by Badan Tanmiah. Although the amount of the investment is not as much as the government's funds, it reflects the concern of Badan Tanmiah to the Muslims through the development of the waqf property which needs to be further enhanced. Among the hospitals that received the proceeds from the fund was the King's Wife Hajah Saleha Hospital (RIPAS).

One of the missions of Badan Tanmiah in achieving its goal of paying attention to the welfare of Muslims in Brunei Darussalam is to hold a public worship service. Some of the contributions are focused on improving the quality of service, safety, and community amenities in the use of places of worship. Funding of waqf programs to empower places of worship such as mosques and Islamic studies centres was also derived from the investment of waqf investments conducted by them. Most prayer-preservation projects and places of worship are carried out slowly. Among the successful projects were the construction of jetty at the arts and crafts building of Jalan Residency located in Brunei and Muara district in 2001, the preservation of surau and worship places of Kampong Saba, Kampong Pandan River, Kampong Mata-Mata, Kampong Tanjung Bunut and Kampong Located in Brunei and Muara in 2005, the preservation of the prayer and worship of Kampong Melilas and Kampong Sukang located in the Belait district in 2006, the preservation and worship of Kampong Semabat and Kampong PiasauPiasau in the Temburong area during the year 2007 and the maintenance of the surau and the worship center of Kampong Sungai Pandan located in Brunei and Muara in 2008. In addition, the assistance program provided by Badan Tanmiah for distributing the investment income of waqf property is not limited to money or goods but services. For example, blood donation 
services at Unit B10, Baitulmal Trade Building, Jalan Kota Batu. It was held as one of the charitable initiatives by Badan Tanmiah for the community and has received tremendous response. About 50 people volunteered to donate their blood throughout the program. In fact, such activities can help promote Badan Tanmiah to the communities and communities in Brunei Darussalam.

\section{Weaknesses}

Not all waqfs in Brunei Darussalam are registered under MUIB. There are two types of waqf that exist today that are registered waqf and unregistered. The registered waqf is a waqf registered and registered under MUIB. While unregistered waqf is waqf which is usually handed out directly to the waqf beneficiary or pronounced in front of witnesses without being registered under MUIB. This is a continuation of the absence of a specific law or Act that requires all property in Brunei to be registered under MUIB. Absence of records and registered data on waqf property has made it difficult for MUIB to monitor and maintain the waqf property. The restructuring of waqf data in MUIB has only been started since 2008. Among the unregistered waqf land is Haf Basir bin Saban. MUIB was also unable to record some status of the waqf land, either general or special as a result of incomplete waqf documents in the waqf property file. Given this problem, MUIB was unable to accurately determine the amount of waqf and the extent of landfill existing in Brunei Darussalam. The less systematic data management at MUIB also made it difficult for them to contact the appellant if any problems needed to be resolved jointly with the waqf giver.

Among other problems is the delay in the validation of the landfill. The MUIB had to go through some lengthy process of management and development of the waqf property as it had to go through processes such as land measurement and subdivision in various departments besides MUIB, for example in the Land Department. This can be seen in the development of a special waqf land for a mosque in Kampong Kilanas. MUIB has been accepting the application of waqf since 1986 and due to the need for certain processes, construction of the mosque was only commenced in 2010. The development of the waqf land has taken 24 years to obtain the consent of His Majesty Sultan and the President of Brunei Darussalam in 1990 and only approved by the Land Commissioner after 13 years, to build a mosque on it. Lack of expertise in management and development of waqf property is also a challenge in managing and developing waqf land. Officers stationed at MUIB lack the expertise, experience and extensive knowledge of waqf especially in the field of planning and technical. Despite the fact that the Badan Tanmiah is responsible for developing and investing in waqf real estate, the absence of experts at MUIB has made it difficult to manage and plan the development of waqf together. To date, officials at the Badan Tanmiah have been involved in investing solely in waqf property without engaging in research and development related to waqf property. Research and development of waqf property is very important because of the research and research carried out, the parties can plan the suitability development and potential of real estate that can be developed and developed for the advancement of the Muslim community. The Land Office also has no long-term and short-term strategic plans for developing and investing waqf property. a sluggish economy has led tenants to seek more economical and strategic business premises such as Lot 11106, Kampung Batu Block B.

Human resources are very important in the management of an organization especially involving waqf. The shortage of staff in MUIB's waqf and baitulmal divisions caused them to carry too much workload and unable to fully focus on the aspect of waqf. As a result, there is no specific monitoring and ongoing monitoring of the waqf lands in Brunei. Monitoring is only done in the event of any complaints or instructions from the superior. As a result of this lack of 
continuous monitoring, there was a demolished waqf without the knowledge of MUIB such as Awang Haji Nasir bin Haji Abu Bakar's waqf, which involved houses being used for worship and religious studies in Kampung Dato Gandi, Brunei (Waqf and Baitulmal Divisions, n.d) .The provisions of the law relating to the Islamic State of Brunei Darussalam are contained in the Islamic Religious Council Act 77. However, the content of the provisions has not been updated since it was enacted in 1956. The provisions are inconsistent and concise and pose problems in management and development of waqf land in Brunei. If any problem arises, they will refer to the Islamic law which has been promulgated by the Government of Brunei Mufti. In addition, wills and vows are also provided in conjunction with the waqf of this Act and this can be seen in Section 102 (1), where this section limits the waqf allowed to be only $1 / 3$ of the appellant's property held either in good health or pain approaching death:

"Whether or not it was made by will or gift at death, the waqf or vows made after the commencement of this Act and involving more than one-third of the property of the person making the waqf or vows are invalid in respect of more than one-third of that, unless in fact approved by His Highness in writing”.

This provision clearly contradicts the concept of waqf in Islam because waqf worship can be performed by Muslims without any limitation. Islam allows the appellant to define as much of the waqf property as he wants to give without the maximum limit and it is considered valid if it meets the rules and conditions of the waqf in Islam. In fact, waqf is also not limited to being in a healthy state; it is also acceptable in a medical condition. However, in the context of Islam, waqf is only limited to $1 / 3$ made by will and when illness approaches death (maradh al-maut) because at present the practice of waqf takes the law of the will. The provisions of this Section 102 (1) give rise to the misconception of the practice of waqf in a state of health and illness. The practice of waqf is divided in the form of sickness approaching death (maradh al-maut), will or health. separately by naming it the General Wax Fund. This is explained in the provisions of Chapters 103 (1) and (2) of the Islamic Religious Council Part 77:

103. (1) "Income from a special waqf, if accepted by the Council, shall be borne by it in accordance with the legal terms of such special waqf."

103. (2) "Income from every other waqf and every general vow should be paid and be part of the General Waqf Group."

However, the MUIB does not set aside any monies earned either from special waqf or general waqf. MUIB has consolidated all this money into the General Administration Fund, which comprises various sources such as bank interest (money) submitted to MUIB, marriage registration, marriage and polygamy, marriage certificate fees, divorce and referrals, fines from Shariah Courts, never-ending property, certificates, certificates, licenses, import permits and halal marks, slaughtering certificate fees and more. The same is true of the Land Agency, which is the revenue or income derived from the development of waqf property consolidated into the development money account and investment of baitulmal property. Apart from the above issues, MUIB is also facing the problem of landfill reporting in Brunei. Pursuant to the provisions of the Islamic Religious Councils Act 77 Section 107, 108 and 109, MUIB is required to publish a list of waqf assets, financial reports, balance sheets and reports of activities of the Council at least once in three years and publish them in the Government Gazette. All of these lists should also be audited as provided in Section 108. However, MUIB failed to publish them as required by these sections. 


\section{Opportunities}

Brunei has great potential in developing and developing real estate and cash waffles. Given that Brunei is a small country, the lands in Brunei Darussalam are of high value and profitable for the sake of the Muslims. At the same time, cash waffle funds have yet to be fully realized. Until 2019, cash waffle benefits will be distributed to religious schools and KUPUSB only. There are no major high impact projects that have been implemented as a result of the accumulated cash waffles (Interview, 2019a). With strong economic conditions and government assistance, Brunei certainly has a good chance of gaining a good market for investment in various sectors such as education, health and others. To undertake such mega projects, MUIB and the Land Agency can collaborate with real estate developers and Islamic banks throughout Brunei.

\section{Threats}

Most people in Brunei still have no understanding of waqf worship. Most Muslim people still think that waqf is only limited to religious activities such as mosques, mosques and tombs purely without any element of the production and investment of waqf property. This has little to do with disturbing the development, development and potential of the waqf in Brunei. As of March 2019, MUIB owns 46.25 acres of customary landfill and a total of 10.8825 acres. There is a significant difference between the special waqf land and the general waqf. $98 \%$ of this special waqf land is intended for special use involving mosques, mosques and tombs (Interview, 2019a). From 1989 to 2017, the total amount of cash donations collected at MUIB and successfully distributed to beneficiaries in accordance with the intention of the beneficiary was B $\$ 3,963,229.28$. However, $90 \%$ of this cash is allocated to the construction, improvement, enhancement and renovation of mosques throughout Brunei's country. Only $5 \%$ is intended for the general use of the Brunei Muslim community (Mohammad Adly Kasyfullah, 2019). The MUIB also accepts movable property such as equipment for mosques, schools or institutions of higher learning through the Waqaf Tarbiyah Program. From 1982 to 2016, 198 units of air-conditioned waffles for mosques, 81 carcasses and equipment wafers such as chairs, books, Quran, microphones and printers were accepted and distributed to religious schools and colleges, Seri Begawan Religious University (KUPUSB) (Interview, 2019a).

Inadequate physical condition of waqf land is one of the challenges faced in developing waqf land in Brunei. Small land size, poor land quality and poor strategic position and economic inability are among obstacles in the development of waqf real estate. The case where the customary waqf land could not be developed is the Dayang Hajah Siti Hajar binti Awang Haji Othman (Jerudong Religious School, 2011). However, after examining and taking into account factors such as the location and area of the land, the MUIB considers that the land is not suitable for a shrine or shrine as it is located in a strategic location and is suitable for commercial or business purposes. The MUIB had previously planned to build a business building on this waqf land by turning the basement into a mosque to realize the intention of the waqf giver. MUIB later requested a ruling from the Brunei Government Mufti on the matter. The Mufti believed that the land of the waqf could not be developed unless it was in accordance with the intention of the waqf to erect a surau on it. Due to certain issues, MUIB has not yet made any development on the land and the land is still in their storage. In addition, there are cases where the land can't be developed due to physical problems such as the case in Kampong Mulaut. The land is rectangular, has a width of 0.97 acres and is located not far from the Sultan Sharif Ali Mosque. Originally, the person who performed the waqf with the intention of establishing a mosque on the land, but later he changed his original intention to the general waqf which is for the common good of the Muslims. The waqf giver has given the trust to MUIB to develop the land granted. Due to the physical problems inherent in the waqf land, MUIB has submitted 
the land to the Land Agency to design the most suitable development project on the land. Badan Tanmiah took a long time to plan any project on waqf land and this has caused the beneficiary to decide to take back the waqf land and develop it himself. However, MUIB rejected the application of the beneficiary of the appellant because in accordance with Islamic law, the waqf could not be withdrawn, especially when the applicant had clearly and legally signed the waqf. The Land Agency is also facing the problem of shortage of land for development. Most of the land developed by the Land Agency is heirloom and baitulmal land, prayer and religious schools (Mohiddin, HHM N \& Yusof, K., 2017). The implication is that there is less promotion and publicity about the development of waqf property as there is not a lot of land development that can be promoted by Badan Tanmiah. In addition to the shortage of waqf land, the long and costly development of waqf land in Brunei has also made most Brunei people prefer to vacation outside Brunei. To date, there has been no development of waqf property which can serve as a prime example in Brunei Darussalam.

Meanwhile, MUIB and the Legal Committee issued a ruling taking into account the final opinion of the Shafie scholars as enshrined in the Islamic Religious Council and the Supreme Court of Justice Act 77, Section 43 (1) (Brunei Mufti Department, 2011):

"In making and giving any fatwa in the manner prescribed before the Council and the Legal Committee shall normally follow the qaul (statement) of the Shafie scholars."

The provisions of this Act indirectly make the method of istibdal waqf inapplicable in Brunei Darussalam because the final opinion of the Shafie sect states that the waqf land can't be sold or replaced with other lands. Brunei Darussalam Government Mufti has issued a fatwa on this view and has not approved the waqf to be practiced in Brunei. Therefore, the undeveloped waqf lands are only kept by MUIB without being developed. Brunei adheres to the Shafie sect in the laws regarding cash waqf. Therefore, they don't agree to invest the accumulated cash waqf funds because it is feared that the principal value of the waqf will decreased. Cash accumulated funds received by MUIB will continue to be handed over to the Finance Department without any investment planning (Interview, 2019a). The income of Badan Tanmiah depends on the development and investment of baitulmal lands and waqf, which is through development rent and investment carried out by them. However, low rental rates, arrears of rent that have yet to be paid by tenants have consistently caused the Badan Tanmiah to lack capital in planning future development. In some situations, the income of the Land Agency depends on the current economic situation. The economic downturn also indirectly affects the income of the Agency. The development of baitulmal properties and waqf at the Land Agency was also funded by MUIB through the General Administration Fund. Funding approved by MUIB is limited on an annual budget and the Land Agency is not given specific funding or capital to develop and invest in waqf properties. The allocation provided should take into account the development of baitulmal properties and the incremental development rental income incurred resulting in limited income being paid to pay salaries, maintenance and annual taxes without being able to carry out other development and investment activities. In the accounting aspect, too, all the revenue obtained by the Land Agency is consolidated together with the baitulmal properties (Waqf and Baitulmal Divisions, n.d). These accounting practices make the Land Agency difficult to plan development because they do not know how far the development of waqf property will benefit or not.

\section{Suggestions and Recommendations}

MUIB should systematically develop data systems to address unregistered waqf problems. With the data restructuring and logging done, MUIB is able to plan development and 
investment of waqf real estate jointly with Badan Tanmiah. Short-term and long-term planning should be established in developing and investing in real estate. Strategic planning can be accomplished by holding roundtable discussions or focus groups with experts from various fields such as real estate, investment, finance, law, development, engineering, architecture and waqf. As a result of these discussions, MUIB may issue a Strategic Plan or Master Plan within 5 to 10 years to serve as a guideline and annual work target for all staff involved in the field. In drafting a strategic plan, MUIB and the Land Agency should consider aspects of the sustainability of the waqf institution from various angles. MUIB can also develop Standard Management Procedures to expedite the process of validating the landfill. Amendments may be made to further the verification process with the active involvement of the units or sections involved. Officials working at MUIB and the Badan Tanmiah should always be given exposure, training and extensive knowledge of investment and the role of productive waqf in Brunei. The concept of productive waqf should be explored more widely. In this way, the waqf property can be generated, developed, leveraged together and eventually maintained. Increase in staff at MUIB and the Badan Tanmiah can be done in stages to save costs and hire contract workers before being offered a permanent position.

MUIB as a body under the Government of Brunei is required to comply with all provisions of the Islamic Religious Councils Act and the Courts of Criminal Procedure 77. Failure to comply with such laws is required to create a negative public perception of MUIB as a whole. Waffle reporting is very important as it involves the Muslim community in Brunei. In the absence of a transparent and accessible annual report, issues of accountability, transparency and accountability will result in the loss of MUIB's reputation and reputation. This will undermine the public's confidence to invest in and invest in waqf property in MUIB and Badan Tanmiah. In order to distribute the benefits of the waqf, Badan Tanmiah must balance various sectors in order for holistic development to take place. The distribution of benefits and investments can also be focused on the health, religious and social sectors. Even waffle property development projects can also be carried out in collaboration with developers, contractors, banks and Islamic financial institutions. In this way, any deficiency on the part of Badan Tanmiah can be managed efficiently as it is accommodated by others. The mechanism of continuous monitoring of waqf properties can prevent many problems on waqf land such as encroachment, while also reducing the cost of buildings maintenance under the management of Badan Tanmiah. Badan Tanmiah proposed adopting the concept of building facilities management, operation and maintenance in monitoring and maintaining buildings built on waqf land. On the issue of law, the authorities and lawmakers in Brunei need to rethink the amendments that can be made to the existing legal framework, the Islamic Religious Council Act 77. Provisions on waqf should be supplemented especially with regard to respondent procedures in particular. For provisions seen to be misleading to the public such as the practice of dying in a case of near-death (maradh al-maut), will or health, it is necessary to make immediate changes as it relates to Islamic law. In addition, the Mufti is also urged to examine and celebrate the various views of the sect in the Islamic law and decide the law according to the rationale and prejudice of the Muslim community in Brunei in the case of the property of waqf. Finally, to help solve the problem of funds, MUIB can work with Islamic financial institutions such as banks and cooperatives by adopting equitybased investments such as musharakah and mudharabah or in the form of murabahah to maximize cash waqf. The proceeds from this cash waqf collection can be used to finance the development and investment of waqf real estate jointly with the Badan Tanmiah.

\section{Conclusion}

In conclusion, based on the SWOT analysis, the strength of the waqf governance in Brunei is the strength of religion in the country where Muslims are the majority, the successful 
governance practices of MUIB and Badan Tanmiah that enable them to generate high income and benefit the people from the income of waqf property and direct financial assistance from the government. In view of its weaknesses, there is still the potential of unexplored waqf, problems in human resources and management as well as slowing the growth of waqf development compared to other neighbouring countries. On the other hand, the is still some great potentials of landfill and cash waqf. Threats include lack of awareness and understanding of waqf among Islamic waqfs and resource constraints. In the context of Brunei, the development and investment of waqf real estate is managed by the Badan Tanmiah in collaboration with the Brunei Islamic Religious Council. Although there are lands that MUIB has successfully developed, the development is still to a minimum. There is much potential that the Badan Tanmiah and MUIB need to address in managing the development and investment of waqf property in Brunei. Although the development and investment of waqf real estate has had to face many challenges, MUIB and the Badan Tanmiah have been seen as positive and proactive in resolving issues and issues that have been around for a long time. Overall, the awareness and cooperation of all parties is essential in helping to increase the potential for development of the waqf in Brunei Darussalam.

\section{References}

Abu Bakar, M. (2019). Pengurusan Pembangunan dan Pelaburan Hartanah Wakaf: Pengalaman Badan Tanmiah Harta Brunei Darussalam. dlm. Pemerkasaan Filantropi Islam di Malaysia. Selangor: Institut Kajian Zakat (IKaZ).

Akta Majlis Ugama Islam dan Mahkamah-Mahkamah Kadi Penggal 77. (1956). Brunei: Kerajaan Brunei Darussalam.

Badan Tanmiah Harta Majlis Ugama Islam. (2015). Buletin Tanmiah, Brunei: Majlis Ugama Islam Brunei.

Badan Tanmiah Harta Majlis Ugama Islam. (2019). https://badantanmiah.com/. Retrieved on 23 September 2019.

Bahagian Wakaf dan Baitulmal. (n.d). Mewakafkan Tanah. Brunei: Jabatan Majlis Ugama Islam Brunei.

Bahagian Wakaf dan Baitulmal. (n.d). Pengurusan Wakaf di Negara Brunei Darussalam. Brunei: Jabatan Majlis Ugama Islam Brunei.

Gani, H. A. R. (2015). Perkembangan Wakaf di Negara Brunei Darussalam. Jurnal Kolej Universiti Perguruan Ugama Seri Begawan. Brunei: Kolej Universiti Perguruan Ugama Seri Begawan, 63-71.

Hubur, A. A. (2019). Productive Waqf Management: A Case Study of Brunei Darussalam. International Journal of Islamic Business. June, Vol. 4, Issue 1, p 65-87.

Jabatan Mufti Kerajaan Brunei. (2011). Himpunan Fatwa Mengenai Wakaf. Brunei: Jabatan Kerajaan Brunei.

Majlis Ugama Islam Negara Brunei Darussalam.(2018). Kuasa, Tugas dan Tanggungjawab. Berakas: Majlis Ugama Islam Brunei.

Majlis Ugama Islam Negara Brunei Darussalam. (2019). http://www.kheu.gov.bn/Theme/Home.aspx. Retreived on 23 September 2019.

Mohiddin, H. H. M. N \& Yusof, K. (2017). Memasyarakatkan Wakaf di Brunei Darussalam:Realiti dan Cabaran. Paper work for ASEAN International Conference on Islamic Finance $\quad\left(5^{\text {th }}\right.$ AICIF). Bandar Seri Begawan, $17 \& 18$ December.

Rangkuti, F. (2000). Analisis SWOT Teknik Membedah Kasus Bisnis.Jakarta: Gramedia Pustaka.

Sekolah Ugama Jerudong. (2011). Profile Sekolah Ugama Jerudong, Brunei III, Sekolah Ugama Jerudong, Jabatan Pengajian Islam, Brunei: Kementerian Hal Ehwal Ugama Brunei Darussalam. 
Tamit, H. H. S. (2010). Pentadbiran Undang-Undang Islam di Negara Brunei Darussalam pada Zaman British. Kertas kerja Seminar Sejarah Brunei III, 100 Tahun Hubungan Brunei- British 1906-2006. Brunei: Pusat Sejarah Brunei.

Interview. (2019a). Mohammad Adly Kasyfullah bin Haji Jaafar. Pegawai Bahagian Wakaf dan Baitulmal, Jabatan Majlis Ugama Islam, Kementerian Hal Ehwal Ugama, Negara Brunei Darussalam. 7 March.

Interview. (2019b). Awang Mahdini bin Haji Merali. Pegawai Bahagian Wakaf, Badan Tanmiah Harta Majlis Ugama Islam Brunei, Jabatan Majlis Ugama Islam, Kementerian Hal Ehwal Ugama, Negara Brunei Darussalam. 7 March.

Yusof, K \& Mohiddin, F. (2011). Pendapat Fuqaha dan Kesannya dalam Pelaksanaan Inovasi Wakaf di Brunei: Satu Tinjauan Awal. Jurnal Syariah Brunei.pp: 71-85. 